\title{
Historical Dynamics of the Anti- Corruption War in Nigeria
}

\author{
Oluwatobi, O. Adeyemi (PhD) ${ }^{1 *}$ Julius Olaniyi Adeoye (Ph.D $)^{2}$ \\ 1. Department of Local Government Studies Obafemi Awolowo University Ile- Ife, Nigeria. \\ 2. Department of Political Science and Public Administration, Adeleke University, Ede, Osun State, \\ Nigeria
}

\begin{abstract}
This paper deals with the discourse on historical dynamics of the anti- corruption war in Nigeria. The culture of corruption has been the major problem of governance in Nigeria and this has negatively affected the external image of the country as the nation has consistently remained one of the most corrupt nations in the world. Methodologically, the paper adopted a qualitative research technique of data collection through the content analysis of various studies conducted by scholars who have made outstanding contributions on the practice of governance and anti-corruption policy within and outside Nigeria. The findings from the study reveals that, despite the establishment of various anti-graft agencies, incidences of corruption continue to abound in Nigeria and various efforts by individual and different stakeholders in anti-corruption campaigns has not achieved any meaningful results. The study therefore, recommends that, in combating corruption at all levels of government and institutions, the government must amend the Penal and Criminal Code (law) which were outdated and drafted over fifty year ago when the country faced lesser crime. The sanctions contained in these laws are insufficient to the offence committed. These laws must be amended in line with the Chinese legal system which lay emphasis on stiffer sanction on corrupt practices. Life imprisonment should melted out on any official who steal above N15 million naira and death penalty for N100 million above.
\end{abstract}

Key words: Corruption, Anti-graft, Governance, Bribery, Penal Code, Criminal Code.

DOI: 10.7176/PPAR/9-9-08

Publication date:September $30^{\text {th }} 2019$

\section{INTRODUCTION}

One of the major problems of contemporary Nigeria is corruption. It has thrived, progress and deeprooted in the system (Adeyemi 2012:190). It is indeed a truism to say that over the years, corruption has become both systemic and endemic, so much that the averages Nigerian until recently have come to accept it as the normal way of life. Many indeed see the occupying public offices as a means of acquiring illicit wealth or enriching themselves through corrupt means.

Historically, crisis of governance especially large scale corruption began with the advent of military rule in Nigeria in 1966. There was abysmal looting of the Nigeria treasury especially those of Ibrahim Babaginda and Sani Abacha. Succeeding military regimes have been more corrupt than those they topple and which they had initially accused of corruption (Anifowose, 2005:191). This has negatively affected the external image of the country as the nation has consistently remained one of the most corrupt nations in the world. Nigeria is ranked 144 out of 180 countries in Transparency International's 2018 Corruption Perception Index, making it $27^{\text {th }}$ most corrupt nation in the world.

This image-crisis is a culmination of the plethora of failed attempts by the past governments to eradicate or reduce corruption in the polity. From the Jaji Declaration in 1977 by Olusegun Obasanjo; the Ethical Revolution of Shagari in 1981-83; War Against Indiscipline by Buhari- Idiagbon in 1984; National Orientation Movement in 1986 and Mass Mobilization For Justice by Babangida in 1987; to the War Against Indiscipline and Corruption by Abacha in 1996; it has been a litany of woes between military and civilian leaderships in Nigeria to stem corruption. The seriousness on the part of government to fight corruption propelled the proposal of framework for establishing the ICPC and EFCC during Obasanjo's administration. But despite the establishment of these two agencies, incidences of corruption continue to abound in Nigeria and various efforts by individual and different stakeholders in anti-corruption campaigns has not achieved any meaningful results.

\section{CONCEPTUAL CLARIFICATION \\ The Concept of Corruption}

Corruption as a concept has suffered from what some scholars refer to as a victim of definitional pluralism. Corruption as a term do not have a widely acceptable definition like other terms in social sciences but the explanation of the concept depends on who is defining it, from what perspective and for what purpose. This has to some extent made the attainment of definitional uniformity on this concept within the academia and the 
practicing world of administration difficult. Nevertheless, attempts have been made to explain the concept of corruption. To some, it is the conscious and well planned act by a person or group of persons to appropriate by unlawful means the wealth of another person or a group of person. To others, it is the act of turning power and authority into ready cash.

Bayley (1977) gave added fillip to the general approach to the definition of corruption when he noted that it refers to " a general term covering misuse of authority as a result of considerations of personal gains which need not to be monetary" this definition sees corruption as the selfish enrichment of someone at the expense of the general public. Mariam (1990:426) defines corruption as "inducement offered to someone to wrong by improper or unlawful means such as bribery". Friedrich (1972:122-128), in defining corruption, argues in the following manner:

The pattern of corruption may be said to exist whenever a power holder who is charged with doing certain things, that is, a responsible functionary or office holder, is by monetary or other rewards, such as the expectation of a job in the future, induced to take actions which favour whoever provides the reward and thereby damages the group or organisation to which the functionary belongs (more specifically, the government and, other socio-economic institutions)

McMullan (1969:183-184) defines corruption in the following way: a public official is corrupt if he accepts money or money worth for doing something that he is under duty to do anyway, that he is under a duty not to do so, or exercise a legitimate discretion for improper reasons. Contributing to the discourse Otite (1986) sees corruption as;

Perversion of integrity or state of affair through bribery, favour, or moral depravity. It involves the injection of additional but improper transaction aimed at changing the normal course of events and altering judgments and positions of trust. It consists in doers and receivers' use of informal, extra-legal or illegal act to facilitate matter.

Nwabueze (2002:128) in his own contribution adopted a sociological approach to the definition of corruption. He conceptualized corruption in the following way:
A form of social deviance in some cases, of criminal deviances, the result of failure, or lack of will to respect the norms of social interactions. It is an extra-legal or normative approach to gaining access. It is a form of mal-adaptation involving the acceptance of society's cultural goals and the rejection of the socially approved means of attaining the goals. It is an indictment on the ineffectiveness of society's socialization function; a sign of some defects in the development of citizen's personality system. It indicates the existence of weakness in agencies of social control which should punish rather than reward the perpetuator of corruption.

Corruptions, according to him take several forms. On one hand, if a public officer embezzles public funds kept in his trust that is corruption. In the same view, if he does unauthorized spending or exceeds approved limits for dubious ends, this is corruption. If he, in deviance of the rules, allocates government land to himself, his wife, his child or friends or otherwise appropriates his position to his or other person's unfair advantage it is corruption. If he over values a contract so that he could earn a kick-back, this is corruption. In this connection corruption is synonymous with the abuse of office (Nwabueze, 2002).

The pervasive nature of corruption has created a problem of a universally accepted definition. Heidenheimer (1978:18) classified corruption into three categories. There is the Public Office Centred type which deals with abuse of public trust and official positions and responsibilities for self-serving objectives. At times, this may not result in monetary gains only, for instance showing undue favour to close friends, family and kinship relations in the discharge of public functions.

The second variant is the Market Centred Corruption in which public office is converted to an avenue for the maximization of income and/or property (Heidenheimer 1978). As in the case of former Nigeria's 
President Obasanjo who used his position as the incumbent president to organize fund raising for his private presidential library in Abeokuta where billion of naira was collected from Politicians, Businessmen and private Companies (Soyinka, 2015)

The third variant is the Public Interest Centred Corruption, which emphasizes the abuse of public trust to serve cliental cleavages, communal and other group interests. For instance the citing of government projects in an unviable town because it favours the political leader. This is a common phenomenon in Nigeria.

\section{HISTORICAL TRENDS OF THE ANTI- CORRUPTION WAR IN NIGERIA}

The analysis and understanding of recent anti-corruption crusades in Nigeria require a study of the country's history and internal socio-political processes. This will help us understand when the crusade started and the impact each administration has made since Nigeria independent

The crusade against corruption proposed by the former President Obasanjo during his tenure in 1999 may be the first under civilian or democratic government in Nigeria. It can also be described as the most ambitious ever seen in the country. Nevertheless, it is far from being the first in its history. Corruption and anti-corruption fights have been at the heart of national discourse and action since independence in October 1960 (Enweremadu, 2012).

Corruption has for long been part of Nigerian history. Osoba (2000:471-491) traced the incidence of corruption in Nigeria to colonial days. He notes:

The colonial authorities and their collaborators presided over a fraudulent and corrupt accumulation system, which facilitated the appropriation of huge surpluses for shipment to the metropolis from Nigerian peasant farmers and other petty producers via unequal terms of trade; Nigerian worker via meagre; often below subsistence; wage; all adults via primitive and exorbitant taxation; and entire population (including unborn generations) via exclusive monopoly rights of exploitation granted to British and other European firms over Nigeria's mineral and other natural resources.

During the self-rule period and immediately after Nigeria's Independence, the incidence of corruption began to manifest in the polity. Osoba also pointed out that, in 1956, Foster Sutton Tribunal of inquiry into the African Continental Bank (ACB) exposed how Dr.Azikwe had abused his position as the Premier of Eastern Nigeria by diverting huge sums of money into his own bank. In the same vein, Awolowo and his colleagues who were the leaders of Action Group were indicted by G. B. A. Coker Commission of Inquiry in 1962 for enriching themselves and their party using the accumulated funds of Cocoa Marketing Board, property of the whole people of Western Nigeria. These revelations are shocking because these leaders are seen as models, near-saints by their people (Osoba, 2000). In a different but related development Andreski cited in Agagu (2011:426) observes that;

Until the military coup of 1966, Nigeria was providing the most perfect example of kleptocracy...practically everybody was involved in the kleptocracy circulation of wealth, also the positions in the structure of power were bought, and power itself rested upon ability to bribe.

Since then, Nigeria's public image at international scene has been very negatively affected, as a result of high-level corruption, and every regime had introduced different measures to tackle this menace that is deep rooted in the Nigeria.

The war against corruption in Nigeria dates to a very long time. Every community in Nigeria has mechanisms for dealing with corruption with appropriate sanctions for corruption. This has been sufficiently expressed by Nwakanma (1986:185-186) thus:

In Nigeria, the need to provide the necessary mechanism for controlling corruption has been recognised for a very long time. An ordinance to establish a Criminal Code which made provisions against corruption by public officers was first enacted for part of Lagos and the Southern province in June 1916. Offenders were tried in the ordinary courts having criminal jurisdictions. Today, these provisions have been codified and re-enacted in chapter XII of Criminal Code Law ... of the federation of Nigeria 1958. Sections 98-106 and 114-116 of the said code made copious provisions against offences which can be classified as 'corrupt practices'... the penal code applicable in the northern states of Nigeria contains similar provision. 
The fight against the menace of corruption in public sector came to limelight in January 1966 when the military, led by Major Kaduna Nzeogwu, identified corruption of the politicians as one of the reasons for taking over the administration of Sir Abubakar Tafawa Balewa. According to him:

The aim of revolutionary council is to establish a strong, united and prosperous nation free of corruption and internal strife...our enemies are the political, the swindlers, the men in high and low places that seek bribes and demand ten percent, those that seek to keep the country divided permanently so that they can remain in office as ministers or $V I P$ at least, the tribalist, the nepotists, those that make the country big for nothing before international circles, those that have corrupted our society and put the Nigeria calendar back by their words and deeds (Ademoyega 1981:7).

Saliu and Lipede (2008) observe that, the parliamentary politics in the first republic remained volatile and unstable, and this manifested in a series of fluid coalitions in the country between 1959 and 1964. Greed, corruption and financial mismanagement by leaders aggravated old tensions and grievances, while contested census figures, rigged elections and fears of domination by all groups led to political violence of unprecedented proportions in parts of the country.

General Aguyi-Ironsi who succeeded the civilian regime through Major Kaduna Nzeogwu led coup confronted with the enormous problem of governing a nation on the brink of implosion, General Aguiyi-Ironsi embarked on a unification policy that would bring the whole nation under effective military control. This move, according to him, was necessary to curb the rapid regionalism and ethnic rivalries that had almost sundered the nation and rendered it ungovernable since the incursion of the military into the political arena in January 1966. The unification policy was greeted with protests and riots especially in the North, and it eventually led to the bloody overthrow of the Ironsi's regime two months later in July 1966 (Fawole, 2003).

General Yakubu Gowon, upon assuming power after the July coup abolished the unification policy and ostensibly restored the federal structure. Confronted, however, with secession treat from the East, General Gowon resorted to the creation of 12 more states so as to separate the ethnic minorities in the East from going along with -the Igbo. The act enabled the Federal Government to order a punishing naval blockade of Port Harcourt and deny the secessionist their much needed access to the sea (Fawole, 2003).

After the civil war in 1970, the three "Rs" (Rehabilitation, Reconciliation and Reconstruction were massively embarked upon by Gowon regime with the huge oil revenue that characterised the civil war years (Folarin, 2009). Gowon's administration relaxed the war against corruption as some of his Supreme Military Council members were accused of perpetuating corruption which eventually led to the collapse of his administration. According to Peil (1976:55),

\section{The military government of Gowon, to a great extent, promoted corruption, although the military government said a great deal about 'cleaning up' but little was done to punish the 'kleptocratic' former politicians or to ensure that the new leadership did not follow the examples of the politicians. By the time Gowon was overthrow, corruption was rife in the air. Ten of his twelve state governors were found guilty of acts of impropriety.}

The collapse of Gowon's regime had been attributed partly to his inability to fight the menace of corruption that had been deep rooted in his government. Issues such as his inability to probe Joseph Tarka, the lukewarm manner in which he handled the Ape Aku- Gomwalk affairs, lack of courage to query the corruption of his governors, among others constituted part of his attachment to corruption (Agagu, 2011).

The Muritala/Obasanjo regime, which took over power from Gowon attempted to rid Nigeria of this malady which had retarded the nation's development. This situation prompted the Obasanjo's administration declaration at Jaji in 1977, by which it launched the commencement of the battle against the menace of corruption. In the pursuit of this task, the Murtala/Obasanjo carried out investigation into the assets of Governors who served during the Gowon regime and a lot of what had been looted was confiscated, though, some of the confiscated property was later returned to the owners by another military regime. The regime also carried out the purged of civil service in August and November 1975 as result of corruption among the top echelon of public service that led to the dismissal and retirement of over 11, 000 of public servant.

Regrettably however, the Corrupt Practice Decree No. 38 by which General Muritala's administration sought to purge the country of corruption did not achieve the desired objective. The Corrupt Practice Bureau established under the Act did not make any headway in terms of stemming the surging wave of corruption and corrupt practices (Akanbi, 2005). General Obasanjo, fulfilling his promised and commitment to transition to democratic rule, handed over power to a democratic elected government on October 1979.

The civilian administration of Shehu Shagari which succeeded Obasanjo/Yardua's administration however inherited a constitution which provided for an anti-corruption mechanism which was inadequate. The 
1979 constitution provided for the Code of Conduct Bureau and Code of Conduct Tribunal in section 15 - 20 of part 1 to fifth Schedule of the 1979 Constitution. Nwakama (1986) assessing the inadequacy of the above mechanism observes that:

The Code of Conduct Bureau set up by the 1979 constitution appears to be a victim of legislative inaction on the part of the National Assembly. A statutory provision which neither gives sufficient security of tenure to those who are to operate it ... nor give them the power to hire people of their choice to execute the programme constitute essential inhibitions to effective operation.

In similar vein, Ottong (1986:197) observes that the impact of these constitutional provisions in checking official corruption in the country is very much in doubt because they are sub-systems within a corrupt system. He noted that the impact of the Bureau on official corruption has been negligible. He argued that the constitutional provisions cannot by themselves solve the problems of corruption in Nigeria. The regime also institutionalised the Ethical Revolution Programme as its major step in its drive against corruption in public places. The Ethical Revolution was expected to guide the behaviour of the citizens and to encourage selfdiscipline

In spite of the Shagari government's acclaimed desire to fight corruption, cabinet members, party patrons and other highly placed officials doubted the ability of the president to enforce anti-corruption regulations on the polity. In fact, Alhaji Shehu Shagari was known to have indirectly, in a press interview, said it was only God that could adequately punish corrupt official (Yagboyaju, 2005:183). So bad was the situation that Larry Diamond remarked thus about Shagari's regime:

The character of political leadership was also a problem. It would have been difficult even for the strongest and most heroic leaders to contain violence and corruption generated by high structural premium on state power. But President Shagari never put that proposition to a test. A weak leader prone to governing by consensus, he was unable to control the renal tendencies of his party machinery and closet advisers. The meetings of his cabinet and party council became grand bazaars where the resources of the state were put up for auction (Daimond, 1989; Odunuga, 2001:61)

In view of absence of necessary political will to pursue the ethical revolution programme, Salisu and Lipede (2008), observe that, the then Brigadier Sani Abacha summed up succinctly the travails of four years of presidential system in the country when in December 1983 broadcast to the nation announcing the overthrow of the Shagari's regime as thus:

Our economy has been hopelessly mismanaged. There is inadequacy of food at reasonable prices for our people... Health services are in shambles, as our hospitals are reduced to mere consulting clinics. Unemployment figures have reached embarrassing and unacceptable proportions. In some states, workers are being owed salaries or arrears for eight to twelve months. Yet, our leaders revel in squademania, corruption and indiscipline and continue to proliferate public appointment in complete disregards to our stark economic realities.

The Buhari/Idiagbon regime that succeeded Shagari like Murtala/Obasanjo administration committed itself to fighting corruption and infusing discipline in the society. In this regard, political leaders, minister, governors and some public servant of the ousted regime found wanting were investigated, removed from office and detained.

As a way of sanitizing the society, the War Against Indiscipline (WAI) was introduced with some measure of success in the area of discipline and work ethics. The regime however was short-lived. It was overthrown in what has been described as a 'palace coup' that brought General Ibrahim Babangida to power.

However, the corruption of Gowon's era was a mere child's play when we consider the regimes of Ibrahim Babangida and Sani Abacha. The Babangida's regime was popularly known for its political corruption. Its political transition programme was unending and was replete with all kinds of fraudulent moves that ultimately culminated in the annulment of the June 12, 1993 Presidential Election, reputed to be the fairest and the freest election so far in the annals of the country's political history. According to Osoba (2000)'

The main distinguishing features of corruption in the Babaginda regime was the pervasive culture of impunity; any of his acolytes however high or low in status, could loot the treasury to their heart's content with impunity, provided they remained absolutely loyal and committed to the leader. 
The Babangida administration on its part set up the National Committee on Corruption and other Economic Crimes (NCCEC) under the chairmanship of Justice Eso. However, the report of the committee was never implemented. The Committee identified causes of corruption and made far reaching recommendations and indeed prepared a draft legislation covering:

1. Corruption and Economic Crime;

2. Establishment of Independent Commission Against Corruption;

3. Private Investigation;

4. Establishment of Corrupt Practices Court (Akanbi, 2005:125).

In the pursuit of its own anti-corruption agenda, the Babangida administration established two agencies namely Mass Mobilization for Economic Recovery, Self-Reliance and Social Justice (MAMSER) and National Orientation Agency (NOA). Right from inception the two agencies did not appear capable of fighting corruption because they had no legislative backing or authority to investigate or punish corrupt officials.

In spite of this incapability, the two agencies were allowed to operate huge budgetary allocations and were only accountable to the military president. Like several other agencies that were established by the administration, these organisations were headed by close associates of the president who exploited their closeness to enjoy undue privileges that accompanied such appointments (Yagboyaju, 2005:184).

General Sani Abacha came to power as the Head of State of Nigeria in November 1993 after overthrowing an interim civilian government put in place by Babangida. In 1994, Abacha's administration introduced War Against Indiscipline and Corruption (WAIC). However this anti-corruption programme was a deceit and whitewash initiative from the onset and did not achieve any significant result.

It was the combination of the Babangida's and Abacha's regime that galvanized the international standing of the nation in the year 2000 as one of the most corrupt nations. The two military rulers corruptly enriched themselves and so could not have controlled the menace because they were beneficiaries of it (Folarin, 2009:19). General Abdulsalam Abubakar took over the government as a result of Abacha's death in 1998. The Abubakar regime, according to Adebanwi (2010:24) which executed the transition programme within eleven months, was itself a reflection of the systematic larceny that had come to define governance in Nigeria. There was the unconscionable theft of public resources by the highest decision making body, the Provisional Ruling Council (PRC).

However, of the stated measures by both military and the civilian government were designed to instil discipline in the citizen and probity and transparency in the system. The sad story of it all according to is that, apparently, corruption continued to escalate at alarming rate. Indeed the general belief was that corruption thrives more under the military. The successful military coups in Nigeria, except probably the Gowon coup of 1966, the Babangida coup of 1985 and Abdusalam Abubarkar claimed to have seized power to stop the spate of corruption in the country. Unfortunately, the military turned out to be corrupt, if not more corrupt than those they accused of being corrupt.

On 29 May 1999, a new civilian regime under former president Olusegun Obasanjo was ushered into office. His administration inherited the second most corrupt nation in 1999, and this prompted him to embark on a number of optimistic measures aimed at sanitising the Nigeria society. These include:

(i) Commenced the process of recovery of looted funds from foreign banks;

(ii) Set up ad-hoc panels of inquiry to investigate and report on allegations of corrupt practices especially of failed contracts

(iii) Caused the ICPC and subsequently the EFCC to be established for investigation and prosecution of persons implicated in corrupt practices and economic crimes;

(iv) Initiated reform of the public sector through privatization and commercialization of government business ventures; monetization of benefits of public servants, guaranteeing pensions and retirement benefit;

(v) Signed international anti-corruption instruments such as the UN Conventions, the AU Conventions, the ECOWAS Protocol; and

(vi) Seized every opportunity to reaffirm zero tolerance for corruption and the need for ethical and values reorientation (Onuoha, http://www.fes-nigeria.org/common)

Others measures also include: the launching of a new National Orientation Campaign; introduction of a code of Ethics for Federal Ministers and Special Advisers. The code of conduct for Ministers and Special Advisers of the Federal Government of Nigeria subscribes the officers to the seven principles of public life, namely: selflessness, integrity, objectivity, accountability, openness, honesty and leadership (Anifowose, 2002:116).

It must be noted however that laudable as the above measures to curtail the menace of corruption may appear to be, the scourge is still rampant and it is still far from being solved in Nigeria. 


\section{ICPC and Anti-Corruption Crusade in Nigeria}

Independent Corrupt Practices and Other Related Offences Commission (ICPC) was inaugurate on September $29^{\text {th }}, 2000$ as the institutional mechanism for fighting corruption in Nigeria. Section 3(14) of the Act ensures the independence of the Commission as it is not subject to the direction or control of any person or authority.

The Act contains in-built mechanism and institutional framework for fighting corruption. The establishment of ICPC to implement the provisions of the Act is of great significance. The duties of the commission have been spelt out under Section 6(a) to (f) of the Act and summarised thus:

(a) Enforcement: To receive and investigate reports of the conspiracy to commit, attempt to commit, or actual commission of offences as created by the Act and in appropriate cases and prosecute the offenders(s).

(b) Prevention: To study the procedures, system, and practices of public bodies, ministers, parastatals, departments and government agencies with a view to identifying areas that are open or prone to corruption and/ or facilitate same and offer advice, direct or give suggestion on ways and means of preventing likely incidence of corruption and related offences.

(c) Public Enlightenment and Education: To educate and enlighten the public on and against corruption and related offences with a view to enlisting and fostering public support for the fight against corruption. (Akanbi, 2005:130-131).

The ICPC itself is faced at least with two potential challenges which became increasingly obvious as time went on. The first problem was that the ICPC was excluded from investigating cases that occurred before 13 June 2000. In other words, because the anti-corruption Act was signed into law on 13 June 2000, any offence of corruption that was committed before that date cannot be prosecuted by commission. The commission's inability to investigate and prosecute former officials became one of major problem confronting the agency.

The second shortcoming was that the ICPC jurisdiction is limited by the fact that, its excluded several criminal acts taking place outside the public sector such as bank frauds, money laundering, tax fraud, etc. this which most Nigerians considered to be corruption.

Third, there is also weak underfunding and insufficient manpower. The lack of human resources, which define the capacity and effectiveness of all bureaucratic organisations, were a major source of constraints for the ICPC. In similar vein, Adeyemi (2015) observes that, the culture of corruption is rooted deeply in the polity and permeated all the levels and sectors of government; therefore fighting this menace requires much fund. These agencies have cases involving corrupt individuals in virtually all the courts in Nigeria. Therefore, most times they are confronted with challenges of getting funds to prosecute their cases in the law courts, and some of the corrupt politicians who had succeeded in looting government resources while in office end up hiring the best lawyer to stand in for them in court, while the ICPC and EFCC are not able to get funds to prosecute most of their cases. This weak financial base has not allowed ICPC to hire the good and brilliant lawyers or to recruit professional and well experienced investigators

Another factor that has also rendered the ICPC ineffective in its operation is the issue of immunity clause in section 308 of the constitution. This provision was meant to protect these political leaders: The President, Vice President, and 36 states governors and their deputies from incessant litigation, which would distract attention from the serious business of governance. The constitutional provision has made it impossible for ICPC to investigate and prosecute any political office holder that perpetuates corrupt practices while in still in office.

Given these above challenges, it was on the basis of these shortcomings of ICPC that led to establishment of the EFCC by Obasanjo's administration which subsequently became the dominant anticorruption agency in Nigeria.

\section{EFCC and Anti-corruption War in Nigeria}

The historical background to the existence of Economic and Financial Crimes Commission (EFCC) derives from the recognition from the late 1980's of the need to create a special interventionist agency to investigate economic and financial crime. At that time, the menace of Advance Fee Fraud (AFF), with its negative impact on Nigeria had been recognized. At the same time it was recognized that the sophistication of economic crimes were such that there might be need for a special Commission to handle its investigation and prosecution as opposed to regular law enforcement agency (Waziri 2011:28).

By 2002 Nigeria joined the list of Financial Action Task Force of Non-Cooperative Countries and one of the conditions for being taken off that list was compliance with the recommendation 26 of Financial Action 
Task Force's 49 recommendations which required the creation of a Financial Intelligence Unit (FIU). Consequently, the EFCC was created in 2002 and Nigeria's Financial Intelligence Unit domiciled therewith. The statue creating the EFCC was created in 2002 and by 2003 EFCC started operation subsequently re-enacted in 2004 (Waziri 2011). The legal instrument backing the commission was the EFCC (Established) Act of 2002 with adequate support from Presidency, Legislature and the key security and law enforcement agencies in the country

Unlike ICPC, the birth of the EFCC witnessed little or no controversy. Although its enabling Act contained more 'draconian' powers than those of the ICPC, its passage in the National Assembly still proceeded almost without any political challenge. There are two explanations for this situation.

Firstly, being legislation that was more or less imposed by powerful international interests, it could not have faced the same kind of political opposition or legislative scrutiny which the ICPC Act attracted. Secondly, and perhaps more importantly, the EFCC bill was not considered a threat by Nigeria's political class, who erroneously interpreted it as a weapon against fraudsters in the banking industry or individuals specialising in advance-fee fraud (commonly known as "419" in Nigeria) (Enweremadu 2012).

\subsection{The Legal Framework of the EFCC}

The Economic and Financial Crimes Control Act 2002 enacted, thus establishing the Economic and Financial Crimes Commission (EFCC). In brief, the Act is divided into seven main parts: Part one establishes the Commission and spells out the composition and tenure of office for members; part two spells out the main functions of the Commission and the special power conferred upon it to tackle the problem of economic and financial crimes.

Part three contains administrative regulations, such as criteria for appointment and other terms and conditions of service for staff, and the establishment of special units for the effective work of the Commission. The offences of financial crimes are defined in part four. These include offences in relation to financial malpractice, terrorism, possession of foreign assets and the retention of the proceeds of crime. It also contains provisions for the seizure or freezing of assets during investigation and forfeiture of such assets after conviction. The jurisdiction for the trial of offences under the EFCC Act is conferred on the Federal High Court or High Court of a State (section 13-25).

Investigative and prosecutor procedures under the Act are determined in part five. These include procedures for the investigation of assets of a person arrested under this Act, the obligation to disclose assets and property by the arrested person, freezing order and banks/financial institutions obligation to comply with such orders, as well the disposal of forfeited property (sections 26-33). Part six contains financial regulations such as the administration of the funds, maintenance of accounts and auditing, as well as annual reports of the Commission in discharging its duties and interpretation of the Acts are contained in part seven (Shehu, 2008).

\section{Anti-Corruption Crusade in Nigeria: The Gains Recorded So Far}

The anti-corruption agency under the administration of Buhari recorded some success in the area of recovery of looted funds and property. Details of the recoveries, published by the Federal Ministry of Information, showed that the Nigerian government successfully retrieved total cash amount N78,325,354,631.82, $\$ 185,119,584.61, £ 3,508,355.46$ and $€ 11,250$ between May 29, 2015 and May 25, 2016. Also released were recoveries under interim forfeiture, which were a combination of cash and assets, during the same period: N126, $563,481,095.43, \$ 9,090,243,920.15, £ 2,484,447.55$ and $€ 303,399.17$. Anticipated repatriation from foreign countries total: $\$ 321,316,726.1, £ 6,900,000$ and $€ 11,826.11$. The ministry also announced that 239 non-cash recoveries were made during the one-year period. The non-cash recoveries are - farmlands, plots of land, uncompleted buildings, completed buildings, vehicles and maritime vessel (FMI, 2017).

The Acting-Chairman of EFCC, Ibrahim Magu, also noted that, the agency, between January and December 2017, recovered more than N473 billion, $\$ 98$ million, $€ 7$ million, and $£ 294,000$ among others. Part of the monies recovered by EFCC in 2017 included N32 billion and \$5 million forfeited to the federal government by former Minister of Petroleum Resources, Alison Madueke (Ayitogo, 2018), Others forfeited are N449 million discovered at a plaza in Lagos, \$43 million discovered in an apartment in Ikoyi area of Lagos, N329 billion from petroleum marketers in Kano while withholding tax of over N27.7 billion was retrieved from banks. Other recovered monies include the Nigerian Ports Authority recovery of $€ 6.6$ million, totalling about N1.1 billion on behalf of AMCON, and the recovery of subsidy fraud funds more than N4 billion (Ayitogo, 2018).

The breakdown of the total recovery is about N738.9 billion or \$2.9 billion between May 2015 and October 20, 2017 (Ayitogo, 2018). 


\section{CONCLUSION AND RECOMMENDATIONS}

This work examines the historical dynamics of the anti- corruption war in Nigerian state. The culture corruption has been the major problem to governance in Nigeria and has negatively affected it external image, as it consistently remained one of the most corrupt nation in the world. The study therefore provided the following policy recommendations as a way of curbing the menace of corruption in Nigeria.

The Nigeria's Criminal Laws should be reviewed to meet up with recent circumstances. The outdated laws have not been helpful to the anti-corruption crusade. The Penal and Criminal Code of Nigeria are over 52 years and probably drafted when the country was faced with minimal and lesser crimes such simple theft, house and shop breaking, smuggling, etc. No one could have imagined then, that the likes of Sanni Abacha, Tafa Balogun, James Ibori, Bode George, etc. who looted government funds in billions of naira could still be born into this generation. The sanctions contained in these two pieces of legislation are not commensurate to the offences they committed and this has sometimes led to public outcry, especially when a convict who stole in billions of naira is convicted and sentenced to jails terms of two years or even less. In combating corruption at all levels of government and institutions, these laws must be amended in line with the Chinese legal system which lay emphasis on stiffer sanction on corrupt practices. Life imprisonment should be melted out on any official who steal above N15 million naira and death penalty for N100 million above (Adeyemi 2018).

The principle of 'leadership by example' should be inculcated in all government establishments. The entire Political office holders, Head of government ministries, department, and agencies including the President, Vice-President, Ministers, Permanent Secretaries, Director-General, Governors, Deputy Governor, Commissioners, Local Government Chairmen, Vice-Chancellors etc, should lead by example so that the culture of honesty and integrity can be institutionalised.

There is urgent need to remove section 308 from the constitution which confers immunity on the President, Vice-President, Governors and their deputies. The section has shielded these set of political office holders from being prosecuted for corrupt practices while in office. Hence, the anti-corruption crusade is worthless and meaningless if the custodians of State resources, that is, President, Vice- President, Governors and their deputies could not be prosecuted if found guilty of stealing government fund while in office. This study therefore recommends that section 308 (immunity clause) should be removed totally from the constitution and should be replaced or amended with serious penalty or punishment for abuse of office and corruption in form of life sentence, death penalty, forfeiting of property and ill-gotten wealth, and ban from holding any political office and chieftaincy title.

There must be aggressive anti-corruption campaign by the electorate and member of civil society. The leaders at all levels must be made accountable to the people. The people should see good governance as their right. Therefore there is need for civil society to demand for transparency and accountability from all government officials. Any incidence of misappropriation of funds by the official of council must be reported to appropriate anti-corruption agency for prosecution (Adeyemi and Oyeleye, 2014). This will promote and encourage accountability and transparency on the part of political office holders.

\section{References}

Adebanwi, W. (2010). A Paradise for Maggots: The Story of a Nigerian Anti-Graft Czar. Nigeria

Ademoyega, A. (1981) Why We Struck. Ibadan: Evans Brothers

Adeyemi, O. O. (2012) "Corruption and Local Government Administration in Nigeria: A Discourse of Core Issues”, European Journal of Sustainable Development, Vol. 1, No. 2, European Centre of Sustainable Development

Adeyemi, O. O. (2015) "Institutional Mechanism Against Corruption in Nigeria: An Appraisal of Independent Corrupt Practices and other Related Offences (ICPC) and Economic and Financial Crimes Commission (EFCC)" Unpublished PhD Research Thesis, Department of Political Science and International Relations, University Abuja, Nigeria.

Adeyemi, O. O. (2018) "Amalgamation and the Crisis of Governance: the Nigeria Experience", Journal of Public Administration and Governance, Vol. 8, No. 3, September, Las Vegas: Macrothink Institute.

Adeyemi, O. O. \& Oyeleye, K. (2014) "Leadership and Challenges of Governances in Local Government Administration in Nigeria”, Journal of Faculty of Social Sciences, 2(1) 63-76, Faculty of Social Science, Benue State University, Makurdi, Nigeria.

Agagu, A. A. (2011). "Ethical Crisis and the Crisis of Underdevelopment in Nigeria", in Agagu, A. A and Ola, R. F. (eds), Development Agenda of Nigerian State, Ibadan: Fiag (Nigeria) Publisher. 
Akanbi, M. (2005) "Corruption and the Challenges of Good Governance in Nigeria", in Olurode, L and Anifowose, R. (eds), Rich But Poor, Corruption and Good Governance in Nigeria. Lagos: Faculty of Social Science, University of Lagos.

Anifowose, R. (2002). “Corruption: A Political Perspectives”, in Adejugbe, M. A (ed), Perspectives on Nigeria's Fledgling Fourth Republic. Lagos: MaltHouse Press Limited.

Ayitogo, N. (2018). EFCC recovered over N500 billion in 2017 - Magu. Downloaded at https://www.premiumtimesng.com/news/top-news/257669-efcc-recovered-n500-billion- 2017-magu.html

Bayley, D. H. (1966).The 'Effect of Corruption in a Developing Countries Developing Nation', Western Political Quarterly, Vol. XIX, No. 4, December.

Brunswick: Transaction Books

Diamond, L (1988). "Nigeria, Pluralism, Statism and Struggle for Democracy" in Diamond L, et al (eds) Democracy in Developing Countries - Africa, Boulders: Lynne Rieuner Publisher. Discourse of Core Issue" European Journal of Sustainable Development, Vol. 1, No. 2, Rome: European Center of Sustainable Development. Downloaded at https://www.premiumtimesng.com/news/headlines/204676-nigeria-publishes-details-of-recovered-assets-withholdsnames-of-looter

Enweremadu, D. U. (2012). Anti-Corruption Campaign in Nigeria (1999-2007): The Politics of a Failed Reform. West African Politics and Society Series, Vol. 1, Leiden: African Studies Centre.

Fawole, W. L (2003). "Military Rule and the Unitarianization of Nigeria" in Olaniyan, R. (ed) The Amalgamation and its Enemies: An Interpretive History of Modern Nigeria, Ile-Ife: Obafemi Awolowo University Press.

FMI (2017). "Nigeria Published Details of recovered Assets, Withholds Names of Looters".

Folarin, S. (2009): "The Anti- Corruption War in Nigeria: A Critical Appraisal of the Role of ICPC and EFCC", Nigerian Journal of Economic and Financial Crimes, Vol. 1. No 2, January - April, Abuja.

Friedrich, C. (1972). The Pathology of Politics, New York: Haper and Row

Heidenheimer, A. J. (1975). Political Corruption, Reading in Comparative Analysis, New

Mariam-Webster (2004). Wesbster's Ninth New Collegiate Dictionary, Massachusetts, USA.

McMullan, M (1961). "A Theory of Corruption”. The Sociological Review, Vol. 9, No. 2, July

Nwabueze, N. (2002). "Corruption: A Sociological Perspective”, in Adejugbe M.A (ed), Perspectives on Nigeria's Fledgling Fourth Republic. Lagos: Malt House Press Limited.

Nwakanma, B. (1986). "An Assessment of Legal Provision for Controlling Corruption in Nigeria" in Odekunle, F (ed) Nigeria: Corruption in Development, Ibadan: Ibadan University Press.

Odunuga, S. (2001). "The Impact of Corruption And Organized Crime in Nigeria's Economy And Economic Development", in Ibrahim L and Odekunle (eds), Fighting Corruption and Organized Crime in Nigeria: Challenges for the New Millennium. Ibadan: Spectrum Books limited.

Onuoha, K. (No Date). 'Anti-Corruption Policies in Nigeria under Obasanjo and Yar'dua: What TO Do After 2011Reflections', accessed at (http://www.fes-nigeria.org/common)

Osoba, S. O. (2000). "Corruption in Nigeria: Historical Perspective" in Mukandala, R (ed) African Public Administration. A Reader: Harare: AAPS Books

Otite, O. (1986). "On the Sociological Study of Corruption" in Odekunle, F. (ed) Nigeria: Corruption in Development, Ibadan: Ibadan University Press.

Ottong, J. (1986). "Toward Effective Control of Official Corruption in Nigeria” in Odekunle, F (ed) Nigeria: Corruption in Development, Ibadan: Ibadan University Press

Peil M. (1976). Nigeria Politics: The People's View, London: Cassel

Salisu, H.A and Lipede, A. (2008): "Constraints of Democracy" in Salisu, H. A, Jimoh, I. H, Yusuf, N and Ojo, E, O (eds), Perspectives on Nation-Building and Development in Nigeria: Political and Legal Issues. Lagos: Concept Publication Limited

Shehu, A. Y. (2006). Economic and Financial crimes in Nigeria: Policy Issues and Options. Lagos: National Open University of Nigeria.

Soyinka (2015) "Obasanjo's Library a Product Fraud, Extortion and Corruption" downloaded at https://www.pmnewsnigeria.com/2015/09/11/obasanjos-library-a-product-fraud-extortion-and-corruption. on August 8, 2019.

Waziri, F. (2011). "EFCC and Challenges of A Growing Economy", in Our Milestones, A Special Publication of Nigeria's Economic \& Financial Crime, Vol. 2, No. 1, May.

Yagboyaju, D. A. (2005). "Impunity Versus Accountability: A Comparative Analysis of Political Corruption under Two Regimes in Nigeria”, in Olurode, L and Anifowose R. (eds), Rich But Poor, Corruption and Good Governance in Nigeria. Lagos: Faculty of Social Science, University of Lagos. 